Jurnal Ekonomi, Bisnis dan Akuntansi (JEBA) Volume 22 No 2 Tahun 2020

\title{
PENGARUH BUDAYA ORGANISASI, TEKANAN, KESEMPATAN, DAN RASIONALISASI TERHADAP PERILAKU KORUPSI
}

\author{
Andita Tyas Ayu Hasuti ${ }^{*}$, Adi Wiratno ${ }^{1}$ \\ ${ }^{1}$ Program Pascasarjana Magister Akuntansi, Fakultas Ekonomi dan Bisnis, Universitas Jenderal Soedirman, \\ Indonesia \\ *Email corresponding : anditahastuti29@gmail.com
}

\begin{abstract}
ABSTRAK
Tujuan penelitian ini adalah untuk menguji pengaruh budaya organisasi, tekanan, kesempatan, dan rasionalisasi terhadap perilaku korupsi. Sampel dikumpulkan menggunakan teknik purposive sampling. Teknik pengumpulan data menggunakan kuesioner dengan responden karyawan yang bekerja di Bank BRI dengan jumlah 70 kuesioner. Analisis data menggunakan regresi linear berganda dengan budaya organisasi, tekanan, kesempatan dan rasionalisasi sebagai variabel independen, dan perilaku korupsi sebagai variabel dependen. Kesimpulan pada penelitian ini yaitu budaya organisasi dan rasionalisasi tidak berpengaruh terhadap perilaku korupsi, sedangkan tekanan dan kesempatan berpengaruh terhadap perilaku korupsi.
\end{abstract}

Kata Kunci : Budaya Organisasi, Tekanan, Kesempatan, Rasionalisasi, Perilaku Korupsi

\begin{abstract}
This study aims to examine the influence of organizational culture, pressure, opportunity, and rationalization on corruption behavior. Samples were collected using purposive sampling technique. Data collection techniques using questionnaires with employee respondents who work at BRI Bank with a total of 70questionnaires. Data analysis uses multiple linear regression with organizational culture, pressure, opportunity and rationalization as independent variables, and corruption behavior as the dependent variable. The conclusion of this research is that organizational culture and rationalization have no effect on corruption 90o8behavior, while the pressure and opportunity affect corruption behavior.
\end{abstract}

Keywords: Organizational Culture, Pressure, Opportunity, Rationalization, Corruption Behavior

\section{PENDAHULUAN}

Kejahatan dapat dilakukan dalam berbagai bentuk kecurangan, salah satunya korupsi. Tindakana kecurangan menggunakan unsur kesengajaan karena individu mengambil keuntungan untuk dirinya sendiri. Korupsi di Indonesia sudah sampai ke berbagai bidang sehingga budaya korupsi tidak mudah untuk dihilangkan. Setelah pembaharuan Undang-Undang Nomor 22 Tahun 1999 tentang Pemerintah Daerah dengan Undang-Undang Nomor 32 Tahun 2004, korupsi bukannya berkurang melainkan menyebar luas tidak hanya ditingkat pusat melainkan tingkat pemerintahan (Dwiputruanti, 2009). Pencegahan korupsi dapat dilakukan apabila kita sudah mengetahui penyebabnya.. Salah satu pemicu untuk melakukan korupsi adalah rendahnya gaji, sedangkan kebutuhan hidup semakin meningkat. Sanksi apabila terjadi perilaku korupsi di Indonesia sudah diberlakukan melalui peraturan yang sudah ditetapkan, tetapi kasus korupsi masih 
saja terjadi dimana-mana. Komisi Pemberantas Korupsi (KPK) sulit untuk mengatasi dikarenakan oleh hal tersebut. Catatan kinerja KPK menunjukkan jum1ah penyelidikan dan penyidikan kasus korupsi selama tahun 2017 lebih banyak dibanding data 2016. Jumlah kegiatan penyelidikan dan penyidikan di tahun 2017 meningkat dibandingkan tahun 2016. Pada tahun 2017, penyelidikan KPK berjumlah 96 kasus. Sementara penyidikan berjumlah 99 kasus. Jumlah kegiatan penuntutan pada 2016 juga hanya sebanyak 76 perkara. Catatan akhir tahun 2017 yang dikeluarkan KPK menyimpulkan bahwa kasus suap tetap mendominasi perkara korupsi. Terdapat 93 kasus suapmenyuap yang dikerjakan KPK pada tahun 2017.

Mendapatkan keuntungan dari hasil yang tidak jujur merupakan bentuk dari fraud (Romney, 2015). Teori yang menjelaskan tentang faktor-faktor seseorang melakukan kecurangan tersebut, yaitu fraud triangle theory atau teori segitiga kecurangan (Cressey, 1953). Teori segitiga kecurangan ini menjelaskan bahwa terdapat tiga faktor yang menyebabkan seseorang melakukan kecurangan, yaitu tekanan atau pressure, kesempatan atau opportunity, dan rasionalisasi atau rationalization (Machado \& Gartner, 2017). Pressure (tekanan) dapat diartikan sebagai suatu kondisi dimana seseorang merasa tertekan saat menghadapi kesulitan yang berat, bisa juga disebabkan oleh kegagalan memenuhi harapan yang diwajibkan, kebiasaan pribadi yang tidak baik, kegagalan bisnis, dan pegawai-bos yang tidak baik. Sering kali kita mendengar tekanan selalu memberikan dampak negatif, sehingga tekanan merupakan salah satu sumber munculnya fraud (Hendra dkk, 2014). Opportunities (kesempatan) biasanya terjadi karena lemahnya system pengendalian yang dimiliki perusahaan. Hal tersebut memberikan celah bagi pihak-pihak yang ingin melakukan kecurangan untuk melakukan tindakannya. Penyalahgunakan wewenangnya oleh para pelaku kecurangan membuat tindakan tersebut sulit dideteksi pihak lain (Zulaikha, 2016). Penyebab lainnya yaitu adanya orang yang memiliki pengetahuan tentang ke1emahan yang ada pada perusahaan serta keahlian untuk melakukkan kecurangan. Rasionalisasi dapat diartikan sebagai pembenaran tindakan dilakukan oleh pelaku kecurangan yang dapat diterima oleh masyarakat. Pembenaran atas tindakannya akan selalu dilakukan pelaku korupsi dengan cara mencari alsan-alasan yang masuk akal walaupun kenyataannya apa yang dilakukannya tersebut adalah tindakan yang tidak benar (Zulkarnain, 2012).

Selain fraud triangle theory, terdapat teori lain yang mendorong seseorang untuk melakukan korupsi, yaitu fraud diamond theory dan fraud pentagon theory. Pengembangan lanjutan mengenai faktor-faktor terjadinya fraud oleh Wolfe \& Hermanson (2004) yang awalnya hanya tiga faktor menjadi empat faktor dengan penambahan kemampuan (capability). Capability menjelaskan bahwa seseorang memiliki keterampilan dan kemampuan untuk melakukan fraud. Pada butir capability ini seseorang mengenali peluang untuk melakukan kecurangan. Elemen-elemen pendukung capability yaitu positioning, intelligence and creativity, convidence, dan coercion. Pada diamond theory, (Crowe, 2010) menambahkan arrogance dan menjelaskannya sebagai sifat keserakahan seseorang dalam menginginkan sesuatu dan menganggap bahwa peraturan-peraturan dan pengendalian internal yang ditetapkan tidak akan berlaku terhadap pelaku kecurangan. Selain fraud triangle theory, budaya organisasi juga dapat memengaruhi seseorang dalam melakukan korupsi. Budaya organisasi merupakan suatu kebiasaan yang ada di organiasasi yang sudah ada sejak dulu dan bersifat turuntemurun hingga sekarang. George dan Jones (2012) menjelaskan budaya organisasi merupakan nilai-nilai dan norma-norma yang dibentuk untuk mempengaruhi cara berpikir dan berinteraksi dengan orang lain yang berada di dalam atau di luar organisasi untuk mengatasi peluang dan memecahkan masalah yang ada di organisasi. Sesuai dengan latar belakang dan rumusan masalah, maka tujuan penelitian ini adalah: (1) Untuk mengetahui dan menganalisis apakah budaya organisasi berpengaruh terhadap perilaku korupsi. (2) Untuk mengetahui dan menganalisis apakah tekanan berpengaruh terhadap perilaku korupsi. (3) Untuk mengetahui dan 
menganalisis apakah kesempatan berpengaruh terhadap perilaku korupsi. (4) Untuk mengetahui dan menganalisis apakah rasionalisasi berpengaruh terhadap perilaku korupsi.

\section{TINJAUAN PUSTAKA DAN PERUMUSAN HIPOTESIS}

\section{Korupsi}

Korupsi berawal dari bahasa Latin corruption dari kata kerja corrumpere berarti busuk, rusak, menggoyahkan, memutar balik, menyogok. Menurut Transparency International Indonesia (TII), korupsi adalah perilaku penguasa publik yang melanggar peraturan untuk menguntungkan diri sendiri dengan cara menyalahgunakan kekuasaannya di dalam instansi (Shoim, 2011). Pada dasarnya masyarakat mengenal istilah korupsi sebagai tindakan yang melanggar hukum untuk memperkaya diri sendiri dengan merugikan orang lain. Penyalahgunaan wewenang atau jabatan yang paling sering mengidentifikasi para pelaku korupsi, sehingga masyarakat menyadari bahwa apabila terjadi korupsi, pelaku korupsi tersebut pasti salah dalam menggunakan jabatannya.

\section{Budaya Organisasi}

Menurut Robbins (2002), budaya organisasi mengarah ke suatu sistem pemahaman bersama yang dipercayai oleh anggota-anggota yang membedakan organisasi itu dari organisasi-organisasi lain. Sistem pemahaman bersama ini, bila diprhatikan dengan lebih mendalam, merupakan satu perangkat karakteristik utama yang dihargai oleh organisasi itu. Sistem pemahaman bersama ini harus dipahami oleh seluruh karyawan agar memiliki pengertian yang sama antara karyawan yang satu dengan yang lain sehingga sasaran/target yang ditetapkan organisasi dapat tercapai. Lingkungan bisnis yang seringkali berubah membuat budaya organisasi perusahaan dipercayai sebagai peningkatan daya saing. Da1am suatu perusahaan, budaya organisasi memiliki sejumlah fungsi. Menurut Robbins fungsi budaya organisasi yang pertama yaitu, budaya organisasi berperan sebagai penentu batas-batas, artinya budaya menghasi1kan perbedaan antara satu organisasi dengan organisasi lainnya. Kedua, identitas anggota organisasi tercakup dalam budaya organisasi. Ketiga, adanya keterikatan terhadap sesuatu yang lebih besar dari kepentingan individu, yaitu kelompok, difasilitasi oleh budaya organisasi. Keempat, budaya organisasi menambah stabilitas sistem sosial.

\section{Teori Segitiga Kecurangan}

Konsep segitiga kecurangan pertama kali diperkenalkan oleh Cressey pada tahun 1953. Salah satu kaki segitiga memvisualkan adanya kebutuhan keuangan yang tidak dapat dibagi dengan orang lain sebagai faktor penekan (pressure). Faktor kedua menerangkan tentang adanya kesempatan (opportunity) dan faktor ketiga menerangkan tentang rasionalisasi (rationalization). Menurut Cressey didalam teori fraud triangle tersebut mengatakan bahwa banyak orang melakukan fraud ketika mereka menyimpan masalah finansial, dan pelaku yakin bahwa cara menyelesaikan masalah keuangan yang sedang dialami yaitu dengan memanfaatkan jabatannya, lalu mencuri atau menggunakan sumberdaya di perusahaan tanpa sepengetahuan manajer.

\section{Elemen-Elemen Segitiga Kecurangan Tekanan (Pressure)}

Tekanan merupakan dorongan untuk melakukan tindakan kecurangan. Tekanan dapat timbul dikarenakan misalnya tuntutan gaya hidup, tuntutan ekonomi, dan lain-lain termasuk termasuk perihal keuagan dan non keuangan. Penelitian yang dilakukan Suradi (2012) menjelaskan bahwa 
Pengaruh Budaya Organisasi, Tekanan, Kesempatan, dan Rasionalisasi

tekanan bisa didefinisikan sebagai dorongan yang muncul didalam diri pelaku kecurangan untuk melakukan tindakan kecurangan. Menurut Sukirman \& Sari (2013) tekanan dibagi manjadi dua yaitu secara financial atau nonfinancial, secara financial dipengaruhi oleh gaya hidup agar terlihat seara bercukupan sedangkan secara nonfinancial yaitu keinginan yang muncul dari diri seseorang demi menutupi kinerja yang buruk.

\section{Kesempatan (Opportunity)}

Kesempatan adalah sebuah keadaan yang memungkinkan bagi manajemen atau pegawai untuk melakukan tindakan fraud. Sukirman dan Sari, 2013 mengartikan kesempatan atau opportunity sebagai sebuah situasi dimana individu mempunyai kemampuan dan kondisi yang bisa membuat pe1aku melakukan fraud dan membuatnya merasa aman dan tidak diketahui oleh orang lain. Tuanakotta (2010) mendefinisikan kesempatan sebagai kemungkinan untuk melakukan kecurangan seperti yang dipersepsikan pelaku kecurangan. Terjadinya peluang disebabkan oleh dua faktor, yaitu: (1) seseorang yang melihat peluang tersebut memiliki keyakinan bahwa aturan yang dilanggar tidak memiliki konsekwensi tertentu, (2) seseorang yang memanfaatkan kesempatan untuk melakukan kecurangan memiliki ketrampilan dan ilmu yang baik (Kuntari, Akram, \& Supaman, 2017).

\section{Rasionalisasi}

Rasionalisasi dapat diartikan sebagai sebuah pembenaran suatu alasan terhadap tindakan kecurangan dan bahwa kecurangan itu meupakan sesuatu hal yang wajar (Gamayuni, 2015). Pelaku yang melakukan tindakan kecurangan berkeyakinan bahwa tindakan yang dilakukan bukan sebuah fraud melainkan adalah sebuah hak pelaku yang harus didapatkan. Hal itu muncul berdasarkan kinerja yang telahpelaku berikan kepada organisasi yang mengakibatkan tindakan yang dilakukan merupakan sesuatu yang benar dan bukan merupakan suatu kesalahan (Zulkarnain, 2013). Rasionalisasi yang dilakukan oleh seseorang dengan beragam alasan untuk menutupi perbuatannya seolah-olah tindakan tersebut wajar terjadi, merupakan bagian fraud triangle yang paling tidak mudah untuk diukur (Syahriani Usman, 2017). Tunggal (2011) menyatakan bahwa rasionaliasi merupakan sikap perilaku atau sekumpulan nilai-nilai bermoral yang memperbolehkan menajemen atau tenaga kerja yang melakukan tindakan tidak jujur atau situasi dimana mereka berada pada lingkungan yang cukup ketat sehingga mereka mengupayakan berbagai cara untuk mencari pembenaran.

\section{Pengaruh Budaya Organisasi terhadap Perilaku Korupsi}

Budaya organisasi diartikan sebagai suatu kebiasaan yang dilakukan secara turun temurun yang membentuk perilaku individu di dalam organisasi. Budaya organisasi dapat juga diartikan sebagai nilai-nilai pembentuk rasa dan mekanisme pengendalian yang menjadi prinsip sumber daya manusia untuk menghadapi permasalahan ekstenal dan upaya penyesuaian diri kedalam perusahaan, sehingga masing-masing anggota organisasi harus memahami ketentuan-ketentuan yang ada dan bagaimana mereka harus bertindak dan bertingkah laku Robbins (2002:283). Budaya organisasi perusahaan dipercaya sebagai basis bagi peningkatan daya saing dalam menghadapi lingkungan bisnis yang akan selalu berubah. Budaya organisasi yang baik akan membentuk sikap dan perilaku yang baik bagi anggotanya dan juga dapat membentuk budaya kerja yang baik sehingga karyawan memiliki kejujuran maupun kualitas kerja yang baik, dan begitu jugaa sebaliknya. Kecenderungan dalam melakukan kegiatan korupsi terjadi apabila budaya organisasi yang terdapat pada suatu organisasi itu buruk. Penelitian yang dilakukan oleh Zelmiyanti dan Anita (2015) menyatakan bahwa budaya organisasi berpengaruh positif terhadap pencegahan kecurangani. Penelitian yang dilakukan oleh Aditya (2013) yang menjelaskan bahwa budaya 
organisasi berpengaruh negatif terhadap fraud di sektor pemerintahan. Hal tersebut terjadi disebabkan oleh dua faktor yang mampu mempengaruhi individu dalam bersikap: (1) faktor internal yang berasal daridalam diri seseorang, (2) faktor eksternal yang bersumber dari lingkungan sekitar seseorang tersebut. Pengaruh terbesar yaitu apabila terdapat rasa ingin melakukan kecurangan yang bermula dari dalam diri individu tersebut. Sehingga hipotesis dalam penelitian ini adalah:

\section{H1: Budaya organisasi berpengaruh negatif terhadap perilaku korupsi.}

\section{Pengaruh Tekanan terhadap Perilaku Korupsi}

Tekanan yang paling sering dialami oleh pelaku korupsi yaitu tekanan yang bersifat finansial. Kebiasaan buruk seperti narkoba, berjudi, kurang dihargainya kinerja, membeli barang di luar kemampuan dan gaji yang rendah dapat memicu karyawan untuk melakukan korupsi. Sehingga apabila tekanan finansial naik, maka tendensi untuk melakukan korupsi juga akan naik. Penelitian yang dilakukan Marliani dan Jogi (2015) menjelaskan bahwa tekanan berpengaruh positif terhadap terjadinya fraud. Hal ini dikarenakan jika pressure bertambah tinggi, maka kecenderungan terjadinya kecurangan juga semakin tinggi. Menurut Lestari (2017) tekanan berpengaruh positif terhadap kecenderungan terjadinya fraud dikarenakan tekanan merupakan aspek yang bersumber dari dalam diri seseorang yang mampu dipengaruhi oleh lingkungan tempat kerja. Sehingga hipotesis dalam penelitian ini adalah:

\section{H2: Tekanan finansial berpengaruh positif terhadap perilaku korupsi}

\section{Pengaruh Kesempatan terhadap Perilaku Korupsi}

Dalam penelitian yang dilakukan oleh Albrecht (2012) menyatakan kesempatan merupakan suatu keadaan dimana seseorang merasa memiliki perpaduan antara situasi dan kondisi yang memungkinkan dalam melakukan fraud dan tidak terdeteksi. Pelaku merencanakan tindakan kecurangan ini karena sudah memahami kelemahan-kelemahan apa saja yang dimiliki system pengendalian internal di perusahaannya. Biasanya pelaku korupsi adalah orang yang sudah lama bekerja di instansi tersebut. Mereka sudah mengamati sistem di instansinya dan mempelajari kelemahan dari suatu sistem yang akan mereka jadikan sebagai kesempatan untuk melakukan tindakan kecurangan. Penelitian yang dilakukan oleh Marliani dan Jogi (2015) menunjukkan bahwa kesempatan berpengaruh positif terhadap kecenderungan terjadinya kecurangan. Kurang ketat dan efektifnya pengendalian internal perusahaan diindikasikan masih terdapatnyna celah bagi karyawan untuk melakukan tindakan korupsi. Dellaportas (2012) menjelaskan bahwa kesempatan merupakan aspek yang mempengaruhi ketika seseorang melakukan tindakan kecuranfan. Besarnya peluang yang ada membuat seseorang semakin berkemungkinan melakukan tindakan kecurangan. Sehingga hipotesis dalam penelitian ini adalah:

\section{H3: Kesempatan berpengaruh positif terhadap perilaku korupsi}

\section{Pengaruh Rasionalisasi terhadap Perilaku Korupsi}

Albrecht (2012) menyatakan bahwa rasionalisasi mampu diartikan sebagai sebuah tindakan justifikasi terhadap dirinya sendiri atau alasan yang tidak benar untuk suatu perilaku yang salah. Rasionalisasi merupakan ideologi yang menjustifikasi perbuatannya sebagai suatu perbuatan yang wajar. Ketika pelaku korupsi melakukan tindakan korupsi, berarti mereka sudah melanggar peraturan-peraturan yang telah ditetapkan. Mereka merasa bahwa perbuatan yang mereka lakukan tersebut adalah perbuatan yang tepat dan mereka tidak mempunyai rasa bersalah saat melakukan korupsi. Rasionalisasi bisa terjadi karena sebagian besar pelaku merasa dirinya tidak melakukan aksi kriminal, tetapi melakukan sesuatu yang memang sepatutnya mereka lakukan. Hal ini yang 
membuat perilaku korupsi menyebar luas dengan cepat dan korupsi adalah suatu peristiwa yang lumrah. Di dalam penelitian yang dilakukan oleh Lestari (2017) menerangkan bahwa rasionalisasi berpengaruh positif terhadap kecenderungan terjadinya fraud. Jika rasiona1isasi semakin tinggi, maka terjadinya fraud juga semakin tinggi. Sehingga hipotesis dalam penelitian ini adalah:

\section{H4: Rasionalisasi berpengaruh positif terhadap perilaku korupsi}

\section{METODE PENELITIAN Jenis Penelitian}

Penelitian ini menggunakan paradigma kuantitatif. Penelitian ini akan menguji pengaruh budaya organisasi, tekanan, kesempatan, dan rasionalisasi sebagai variabel independen terhadap perilaku korupsi sebagai variabel dependen. Data yang akan dipakai dalam penelitian ini merupakan data primer dengan alat bantu kuesioner.

\section{Populasi dan Sampel}

Populasi adalah objek dari penelitian yang karywan yang bekerja di BRI Cabang Demangan, Gejayan, Timoho, Janti, Maguwo, dan Ambarukmo. Metode pengambilan sampel adalah dengan menggunakan convenience sampel yaitu subyek sampel yang dipilih peneliti tidak terbatas sehingga peneliti memiliki kebebasan dalam memilih responden. Kriteria sampel yang digunakan dalam penelitian ini adalah responden yang sudah bekerja di perbankan.

\section{Teknik Pengumpulan Data}

Data untuk penelitian ini dikumpulkan dengan cara menyebarkan kuesioner kepada karyawan yang bekerja di Bank BRI Cabang Demangan, Gejayan, Timoho, Janti, Maguwo, dan Ambarukmo. Kuesioner diberikan secara langsung kepada responden dan responden tersebut mengisi identitas seta menjawab pertanyaan yang sudah tersedia. Pengembalian kuesioner diambil langsung ke responden yang bersangkutan. Kuedioner yang dibagikanberjumlah 80 lembar kuesioner. Dari jumlah tersebut hanya 49 lembar kuesioner yang dikembalikan dan berisi data lengkap, sedangkan 31 kuesioner lainnya tidak lengkap dalam pengisian datanya.

\section{Teknik Analisis Data}

Teknik analisis yang digunakan dalam penelitian ini adalah analisis regresi linier berganda yaitu untuk mengetahui hubungan secara linier antara dua atau lebih variabel independen dengan variabel dependen. Pada penelitian ini akan dianalisis pengaruh budaya organisasi, tekanan, kesempatan, rasionalisasi sebagai variabel independen, terhadap perilaku korupsi sebagai variabel dependen.

Pengolahan data menggunakan program SPSS Versi 15. Persamaan statistic analisis regresi sebagai berikut:

$\mathrm{Y}=\mathrm{b}_{0}+\mathrm{b}_{1} \mathrm{X}_{1}+\mathrm{b}_{2} \mathrm{X}_{2}+\mathrm{b}_{3} \mathrm{X}_{3}+\mathrm{b}_{4} \mathrm{X}_{4}$

Keterangan:

Y : : Perilaku korupsi

$\mathrm{b}_{0} \quad$ : Koefisien beta

$\mathrm{X}_{1} \quad$ : Budaya Organisasi

$\mathrm{X}_{2} \quad$ : Tekanan

$\mathrm{X}_{3} \quad$ : Kesempatan

$\mathrm{X}_{4} \quad$ : Rasionalisasi 
HASIL DAN PEMBAHASAN (Cambria 11, Bold, spasi 1,5, spacing before 12 pt, after 2 pt) Uji Asumsi Klasik (Normalitas)

Hasil uji normalitas dengan menggunakan Kolmogorov-Smirnov Test menunjukkan nilai signifikansi 0,982. Nilai signifikansi lebih besar dari 0,05 yang artinya, data terdistribusi normal.

\section{Uji Multikolinearitas}

Hasil pengujian ini menunjukkan nilai tolerance variabel budaya organisasi sebesar 0,847 , variabel tekanan sebesar 0,660, variabel kesempatan sebesar 0,532, dan variabel rasionalisasi sebesar 0,437 dan nilai VIF variabel budaya organisasi sebsar 1,181, variabel tekanan sebesar 1,515, variabel kesempatansebesar 1,880 dan variabel rasionalisasi sebesar 2,286. Dari data tersebut dapat ditarikkesimpulan bahwa padapenelitian ini tidakaterjadi masasalah multikolinearitas karena nilai tolerance dan VIF pada keseluruhan variabel berada diatas 0,1 dan dibawah 10.

\begin{tabular}{llll}
\hline Variabel & Tolerance & VIF & Keterangan \\
Budaya Organisasi & 0,847 & 1,181 & Tidak terjadi multikolinearitas \\
Tekanan & 0,660 & 1,515 & Tidak terjadi multikolinearitas \\
Kesempatan & 0,532 & 1,880 & Tidak terjadi multikolinearitas \\
Rasionalisasi & 0,437 & 2,286 & Tidak terjadi multikolinearitas \\
\hline
\end{tabular}

\section{Uji Heteroskedastisitas}

Pada penelitian ini, untuk menguji masalah heteroskedastisitas menggunakan analisis Scatterplot. Apabila titik-titik menyebar secara acak, tidak membentuk suatu pola tertentu yang jelas dan titiktitik tersebut menyebar secara merata, maka tidak terjadi masalah heteroskedastisitas.

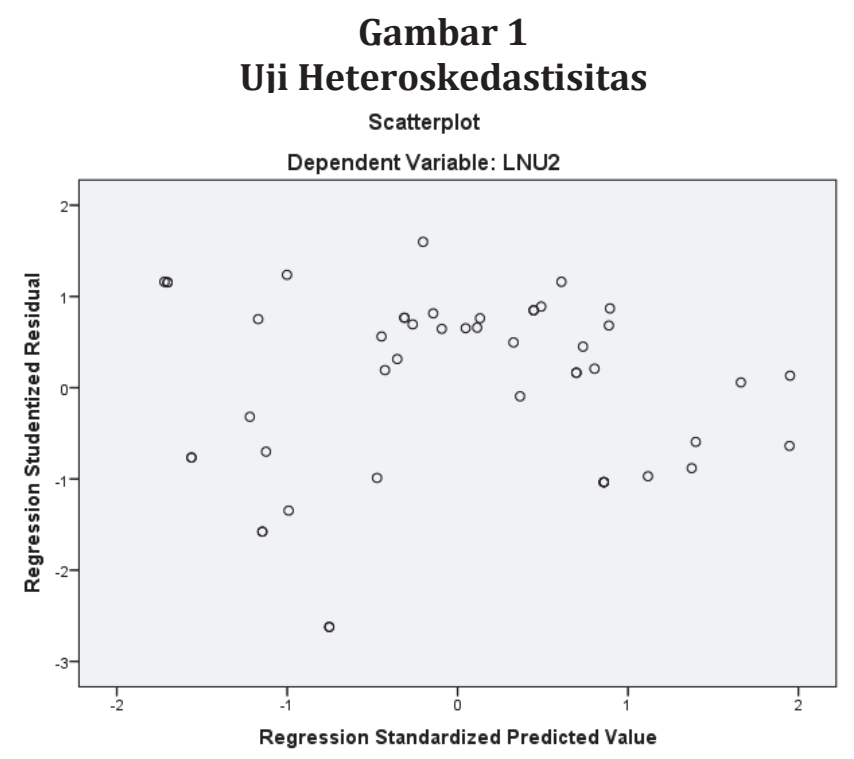

\section{Uji Hipotesis}


Penelitian ini menggunakan analisis regresi linier berganda, yaitu untuk mengetahui apakah ada hubungan anara variabel bebas (budaya organisasi, tekanan, kesempatan, dan rasionalisasi) dengan variabel terikat (perilaku korupsi). Persamaan regresi yang didapat dari hasil pengujian antara lain: $\mathrm{Y}=(0,631)+0,008 \mathrm{X}_{1}+0,787 \mathrm{X}_{2}+0,324 \mathrm{X}_{3}+0,011 \mathrm{X}_{4}+\mathrm{e}$ Keterangan:

$\begin{array}{ll}\mathrm{Y} & \text { : Perilaku korupsi } \\ \mathrm{X}_{1} & \text { : Budaya Organisasi } \\ \mathrm{X}_{2} & \text { : Tekanan } \\ \mathrm{X}_{3} & \text { : Kesempatan } \\ \mathrm{X}_{4} & \text { : Rasionalisasi }\end{array}$

\section{Tabel 1}

Uji Regresi Berganda

\begin{tabular}{lcccc}
\hline \multicolumn{1}{c}{ Model } & $\begin{array}{c}\text { Koefisien } \\
\text { Regresi (b) }\end{array}$ & t-hitung & $\begin{array}{c}\text { Signifikans } \\
\text { i }\end{array}$ & Keterangan \\
(Constanta) & $-0,631$ & & & \\
Budaya Organisasi & 0,008 & 0,000 & 0,922 & Ditolak \\
Tekanan & 0,787 & 4,780 & 0,000 & Diterima \\
Kesempatan & 0,324 & 2,681 & 0,010 & Diterima \\
Rasionalisasi & 0,011 & $-0,093$ & 0,927 & Ditolak \\
\hline
\end{tabular}

\section{Uji Koefisien Determinasi $\left(\mathbf{R}^{2}\right)$}

Koefisien determinasi yakni mengukur sebeapa jauh kemampuan model dalammenerangkan variasi variabel independen. Nilai koefisien determinas adalah antara nol sampai dengan saru. Apabila nilai $\mathrm{R}^{2}$ kecil maka kemampuan variabel-variabel indeoenden dalam menjelaskan variasi variabel dependen sangat terbatas. Nilai yang mendekati satu berarti variabel-variabel independen memberikan hampir semua informasi yang dibutuhkan untuk memprediksi variabel dependen. Variabel yang digunakan pada penelitian ini lebih dari dua, sehingga koefisien determinasi yang digunakan adalah adjusted $R$ square ( $\mathrm{R}^{2}$ yang disesuaikan). Berdasrkan hasil analisis regresi diperoleh nilai $\mathrm{R}^{2}$ yanf disesuaikan sebesar 0,550 atau 55\%. Ini dapatdiartikan bahwa 55\% perilaku korupsi dipengaruhi oleh budaya organisasi, tekanan, kesempatan, dan rasionalisasi. Sedangkan sisanya sebesar $45 \%$ perilaku korupsi dipengaruhi oleh variabel-variabel lainnya yang tidak diteliti dalam penelitian ini.

Tabel 2

Hasil Uji Koefisien Determinasi ( $\left.\mathbf{R}^{2}\right)$

\begin{tabular}{|c|c|c|c|c|}
\hline Model & $\mathrm{R}$ & R Square & $\begin{array}{c}\text { Adjusted R } \\
\text { Square }\end{array}$ & Std. Error of the Estimate \\
\hline 1 & 0,766 & 0,587 & 0,550 & 0,36887 \\
\hline
\end{tabular}

\section{Uji F (Uji Signifikansi Simultan)}

Uji F digunakan untuk mengetahui apakah variabel independen berpengaruh secara bersama-sama terhadap variabel dependen. Apabila nilai F-hitung lebih kecil dari nilai F-tabel, maka keputusannya menerima hipotesis nol (H0). Selain itu juga melihat dari nilai signifikansi dan membandingkannya dengan tingkat signifikansi sebesar 0,05. Berdasarkan hasil penelitian nilai $\mathrm{F}$ hitung sebesar 15,641, dengan nilai probabilitas sebesar 0,000, sedangkan nilai F-tabel 2,816 


\section{Uji Parsial}

Uji t digunakan untuk menguji pengaruh masing-masing variabel independen secara parsial dengan cara membandingkan nilai $t_{\text {hitung }}$ dengan $t_{\text {table }}$ atau dengan membandingkan tingkat signifikansi hasil pengolahan data dengan tingkat signifikansi yang digunakan.

\begin{tabular}{lcc}
\multicolumn{3}{c}{ Tabel 3 } \\
Hasil Uji t \\
\hline \multicolumn{1}{c}{ Variabel } & t-hitung & Sig. \\
Budaya & 0,098 & 0,202 \\
Organisasi & & \\
Tekanan & 4,780 & 0,000 \\
Kesempatan & 2,681 & 0,010 \\
Rasionalisasi & $-0,093$ & 0,927 \\
\hline
\end{tabular}

Variabel budaya organisai memiliki nilai t-hitung sebesar 0,098, t-tabel sebesar 2,015, dan tingkat signifikansi sebesar 0,202. Hal ini menunjukkan t-hitung lebih kecil dari t-tabel dan nilai signifikansi lebih besar dari 0,05, sehingga H1 ditolak. Ini menunjukkan budaya organisasi tidak berpengaruh terhadap perilaku korupsi. Baik buruknya budaya organisasi yang ada pada suatu perusahaan tidak menjamin bahwa perilaku korupsi tidak akan terjadi. Sebab, keinginan untuk melakukan korupsi muncuk dari dalam diri individu, tergantung dari motivasi yang dipunyai individu tersebut, buan dari budaya organisasi.

Variabel tekanan memiliki nilai t-hitung sebesar 4,780, t-tabel sebesar 2,015, dan tingkat signifikansi sebesar 0,000. Hal ini menunjukkan t-hitung lebih besar dari t-tabel dan nilai signifikansi lebih kecil dari 0,05, sehingga H2 diterima. Ini menunjukkan tekanan berpengaruh terhadap perilaku korupsi. Biasanya, tekanan finansial merupakan motivasi yang paling besar untuk melakukan kegiatan korupsi. Gaya hidup berlebihan yang tidak sesuai dengan kemampuan finansialn individu tersebut, terlilit hutang, dan lainnya seringkali menjadi pemicu untuk melakukan korupsi. Apabila tekanan yang dihadapi seseorang itu rendah, maka kemungkinan untuk terjadinya perilaku korupsi semakin rendah juga. Hasil dari pene1itian ini sejalan denegan Albertch (2012) yang menyatakan bahwa semakin tinggi tekanan yang dia1ami seseorang maka semakin tinggi tekanan yang dialami sehingga semakin tinggi kemungkinan individu tersebut me1akukan peri1aku menyimpang.

Variabel kesempatan memiliki nilai t-hitung sebesar 2,681, t-tabel sebesar 2,015, dan tingkat signifikansi sebesar 0,010. Hal ini menunjukkan t-hitung lebih besar dari t-tabel dan nilai signifikansi lebih kecil dari 0,05, sehingga H3 diterima. Ini menunjukkan kesempatan berpengaruh terhadap perilaku korupsi. Lemahnya pengendalian internal biasanya menimbulkan kesempatan untuk melakukan tindakan kecurangan. Pelaku korupsi sudah mengetahui celah-celah rawan yang ada di perusahaannya sehingga mudah untuk melakukan korupsi. Tingginya kesempatan, maka kesempatan untuk melakukan tindakan (Lestari, 2017). Hal tersebut juga sejalan dengan Dellaportas (2012) yang menunjukkan bahwa ketika seseorang ingin melakukan tindakan korupsi, salah satu faktor yang mempengaruhi adalah kesempatan.

Variabel rasionalisasi memiliki nilai t-hitung sebesar -0,093, t-tabel sebesar 2,015, dan tingkat signifikansi sebesar 0,927. Hal ini menunjukkan t hitung lebih kecil dari t-tabel dan nilai signifikansi lebih besar dari 0,05, sehingga H4 ditolak. Ini menunjukkan rasionalisasi tidak berpengaruh terhadap perilaku korupsi. Rasiona1isasi merupakan sikap pembenaran dari peri1aku menyimpang yang dilakukan individu/karyawan. Hasil penelitian ini seja1an dengan penelitian 
Pengaruh Budaya Organisasi, Tekanan, Kesempatan, dan Rasionalisasi

yang dilakukan Cressey (1953) yang menyatakan bahwa pelaku tindakan menyimpang membutuhkan rasionalisai untuk dijadikan pembenaran atas apa yang individu tersebut lakukan.

\section{KESIMPULAN}

Kesimpulan yang dapat diambil dari penelitian tentang pengaruh budaya organisasi, tekanan, kesempatan, dan rasionalisasi terhadap perilaku koruspi adalah: budaya organisasi tidak berpngaruh terhadap perilaku korupsi, tekanan berpengaruh signifikan positif terhadap perilaku korupsi, kesempatan mempunyai pengaruh terhadap perilaku korupsi, rasionalisasi tidak berpengaruh terhadap perilaku korupsi.

Bebeapa keterbatasan dalam penelitian ini yaitu data penelitian yang berbentuk kuesioner yang diisi oleh responden bisa mempengaruhi hasil penelitian. Persepsi yang dimiliki setiap responden bisa berbeda dan belum tentu mencerminkan keadaan yang sesungguhnya. Hal itu akan berbeda apabila proses pengambilan data diperoleh melalui wawancara. Selain itu, untuk pengujian data dalam penelitan ini hanya menggunakan 49 kuesioner dan satu institusi saja. Untuk penelitian selanjutnya, dapat menggunak beberapa instansi dalam penggambilan sampel. Penambahan variabel lain seperti prinsip Good Corporate Governance, pemberian kompensasi, gaya kepemimpinan dan variabel lainnya diharapkan bisa menjadi pengembangan untuk penelitian selanjutnya.

\section{IMPLIKASI}

Berdasarkan hasil penelitian yang sudah dilakukan, terdapat dua aspek yang mempengaruhi seseorang untuk melakukan korupsi yaitu tekanan dan kesempatan. dapat disimpukan bahwa penting bagi kita untuk memberi perhatian lebih pada variabel-variabel yang berpengaruh terhadap kecenderungan seseorang untuk melakukan korupsi. Implikasi dari penelitian ini antara lain: tekanan berpengaruh positif terhadap perilaku korupsi. Hal ini memberikan implikasi agar Bank Rakyat Indonesia (BRI) lebih menghargai kinerja para karyawannya sehingga tidak ada karyawan yang merasa hasil pekerjaannya tidak dihargai. Lingkungan kerja yang nyaman dapat menciptakan situasi yang positif sehingga karyawan tidak merasakan ketegangan/tekanan untuk saling berkompetisi dalam hal gaya hidup. Adanya workshop mengenai mental awareness yang diadakan BRI untuk kepentingan karyawannya juga perlu dilakukan agar karyawan merasa tenang dan cukup atas keadaan karyawan tersebut sehingga kemungkinan untuk melakukan peri1aku menyimpang tidak terjadi. Kesempatan berpengaruh terhadap perilaku korupsi. Hal ini memberikan implikasi agar BRI lebih memperhatikan dan meningkatkan sistem pengendalian intern yang ada pada suatu perseroan. Perbaikan sistem pengendalian intern juga dapat dilakukan secara berkala agar karyawan yang bekerja di BRI yang ingin melakukan tindakan kecurangan atau ingin melakukan korupsi tidak memiliki kesempatan karena tidak ditemukannya celah-celah pada BRI.

\section{DAFTAR PUSTAKA}

Adinda, Y. M. (2015). Faktor yang mempengaruhi terjadinya kecurangan di sektor pemerintahan Kabupaten Klaten. Accounting Analysis Journal 4 (3)

Aditya, M. A. (2013). Faktor-faktor yang mempengaruhi terjadinya fraud di sektor pemerintahan (Persepsi pada dinas se-kota dan kabupaten Pekalongan). Universitas Negri Semarang, Jawa Tengah, Indonesia.

Albrecht, W. S., Albrecht, C. O., Albrecht, C. C., \& Zimbelman, M. F. (2012). Fraud examination (edisi kedua). USA: South-Western Cengage Learning.

Crowe, Howarth LLP. 2010. IIA Practice Guide: Fraud and Internal Audit. Retrieved from http://aibaus.org/wpcontent/uploads/2011/04/2010 0922AIBAFraud.pdf 
Dellaportas, S. (2013). Conservation with inmate accountants: Motivation, opportunity and the fraud triangle. Accounting Forum 37 (1): 29-39

Gamayuni, A. P. dan R. R. (2015). Analisis faktor-faktor yang memengaruhi kecurangan laporan keuangan dengan perspektif fraud diamond (Studi empiris pada perusahaan LQ-45 yang terdaftar di BEI tahun 2009-2013). Jurnal Akuntansi Dan Keuangan 20 (1): 19-34.

Hendra, V. Santana, Y. \& Ghandatama, L. (2014). Fraud triangle. Jurnal Ekonomi Universitas Surabaya.

Kuntari, I. M., Akram, \& Supaman, L. (2017). Determinant and trends of fraud of accounting fraudulent towards financial accountability. International Conference and Call for Papers, Jember, 2017, 23542377

Lestari, C. D. A. (2017). Pengaruh opportunity, pressure, rationalization dan perilaku tidak etis terhadap kecenderungan terjadinya kecurangan. Universitas Pendidikan Ganesha 8 (2): 1-10

Machado, M. R. R., \& Gartner, I. R. (2017). The Cressey Hypothesis (1953) and an investigation into the occurrence of corporate fraud: An empirical analysis conducted in Brazilian Banking Institutions. Original Article. $1-22$.

Marliani, M., \& Jogi, Y. (2015). Persepsi Pengaruh Fraud Triangle Terhadap Pencurian Kas. Business Accounting Review, 3(2), 21-30.

Robbin P. Stephen. (2002). Prinsip-prinsip perilaku organisasi (edisi 5). Jakarta: Erlangga.

Romney, Marshall, and Paul J. S. (2015). Sistem informasi akuntansi (edisi 13). Jakarta Selatan: Salemba Empat.

Shoim, M. (2011). Interaksi antara pelayanan publik dan tingkat korupsi pada lembaga peradilan di kota Semarang. Masalah-masalah Hukum 40 (1)

Suradi. (2012). Mengapa Seseorang Korupsi: Widyaiswara Madya Balai Diklat Keuangan Palembang.

Sukirman, \& Sari, M. P. (2013). Model deteksi kecurangan berbasis fraud triangle. Jurnal Akuntansi \& Auditing, 9(2), 199-225.

Tuanakotta, T. M. (2010). Akuntansi forensik \& audit snivestigatif. Jakarta. Salemba Empat.

Tunggal, A. W. (2010). Dasar-dasar audit internal pedoman untuk auditor baru. Harvarindo. Jakarta.

Usman, S. (2017). Analisis faktor-faktor yang mempengaruhi terjadinya fraud di sektor pemerintahan (Studi pada SKPD Kabupaten Luwu Timur). Universitas Islam Negri Hidayatullah Jakarta.

Wolfe, D. T., \& Hermanson, D. R. (2004). The fraud diamond: Considering the four elements of fraud. CPA Journal 74.12(2004): 38-42.

Zulaikha. (2016). Faktor-faktor yang mempengaruhi procurement fraud: Sebuah kajian dari perspektif persepsian auditor eksternal. Jurnal Akuntansi dan Keuangan Indonesia 13 (2).

Zulkarnain, R. M. (2012). Analisis faktor yang mempengaruhi terjadinya fraud pada dinas kota Surakarta. Accounting Analysis Journal 2 (2). 